\title{
THE ANTONINE PLAGUE IN DACIA AND MOESIA INFERIOR
}

\section{Dragoș MITROFAN}

University „Babeş-Bolyai” of Cluj-Napoca mitrofandragos@yahoo.com

DOI: http://dx.doi.org/10.14795/j.v1i2.53

ISSN $2360-266 \mathrm{X}$

ISSN-L $2360-266 \mathrm{X}$

\begin{abstract}
The study of epidemics, especially the ancient ones, has long eluded our scientists. And so, we have tried to use a different approach and different ways of studying the disastrous effects of such an epidemic, in the $2^{\text {nd }}$ century A.D. The goal of this paper is to analyze aspects such as chronology, expansion, and the effects of the disease, and especially, to raise a question about its presence in the roman provinces of Dacia and Moesia Inferior. Whether the presence of a full scale epidemic can be argued, evidence of disturbance can be found by numerous means. In the end, such scientific approach on epidemics can hold valuable clues regarding the rise and fall of civilizations and empires. Keywords: Antonine Plague, epidemy, mass graves, roman province, plaster
\end{abstract}

$\mathbf{I}$ f one should study the epidemics that have affected the Roman Empire throughout its existence, he would not find any information regarding the subject in the Romanian bibliography. Naturally, one could ask himself if the provinces were either not affected by such disease or the problem itself had not been researched.

Studying the period through which both provinces are part of the massive Roman Empire, a researcher can encounter information of two great plagues: the Antonine plague, or the plague of Galen, and the plague of Cyprian. Both plagues are backed up by written sources and archaeological evidences. In this paper we shall discuss the first of these epidemics, studying the possible effects, such as demography or economical disturbances, on a regional and continental scale.

Galen's commentaries ${ }^{1}$, along with Dio Cassius' history, mention that, following the return of Lucius Verus and his troops from the eastern campaign against the Parthic Empire and at least until the death of the Emperor Marcus Aurelius, a mysterious disease ravaged the Empire, leaving behind millions of victims. In addition, Dio Cassius relates of a similar event in 189 A.D, probably a return of the pestilence, when as much as two thousand people died every day in Rome only. Following this account, there is a similarly interesting description of people dying throughout the empire, murdered with poisoned needles by unseen assassins. ${ }^{2}$ Dio relates this event to one happened a century earlier, during the reign of the Emperor Domitian (aprox. 90-91 A.D). ${ }^{3}$ The interpretation of the latest episode, as some historians see it, as a new method of assassination ${ }^{4}$, seems unlikely. Moreover, taking into account

\footnotetext{
GILIAM 1961, 228.

${ }^{2}$ Dio Cassius 73.14. 3-4.

${ }^{3}$ Dio Cassius 67.11.6.

${ }^{4}$ CREVIER 1814, 345.
} 
that it is related to an epidemic, we plead for some failed medical attempts to cure the disease.

If historians are to have a realistic view on the death toll this disease left behind, they should treat the written sources with caution, ancient writers being known to exaggerate numbers in order to offer a grim and stunning view on their work. The most realistic figures so far can be found in a study, published in the American Journal of Philology by R.J. Littman and M.L. Littman. The two M.D.s bring arguments based on their study on the work of Galen in order to identify the mysterious $2^{\text {nd }}$ century A.D. disease with smallpox $^{5}$. Galen also mentions that the disease travels at a rapid pace, reaching Rome in 166 A.D. and causing important disruption in the legionary troops' camp at Aquileia (168-169 A.D.). In addition, they credit the hemorrhagic form of the smallpox as being guilty of the violent replica in 189 A.D. Unlike their predecessors who plead for an insignificant 1 or $2 \%$ death toll of the population ${ }^{6}$, the authors' estimation reaches as much as $13-15 \%$ for the army and 7 to $10 \%$ for civil population.

For one to understand the implications of a smallpox epidemic, we shall present its pathology. The virus is transmitted from one human to another mostly through indirect contact, such as droplets of saliva resulted from coughing or sneezing. ${ }^{7}$ The smallpox virus is highly infectious: the house of the diseased or personal objects can serve as means of contamination for as much as one year. The diseased are considered prone to infecting others since the debut of smallpox (2-3 days) until the last stage, the desquamation of the specific crusts (5-6 weeks). The disease leaves a certain degree of immunity which usually prevents a future infection. ${ }^{8}$

Another important aspect for this study is spread of the so-called plague. The first mentions of a new, hazardous disease can be traced as early as the siege of Nisibis (165 A.D.) and the siege of Seleucia (165-166 A.D.) ${ }^{9}$ by the legions of Lucius Verus. In A.D. 166, the pestilence reaches Rome, forcing Galen to flee for his home city, Pergamum. In addition, numerous rural and urban sites in Egypt, such as Thoumis, record a fall in the number of tax-payers. ${ }^{10}$

From the archaeological point of view, two mass graves are to be considered essential for this study. The first one is situated in the catacombs of St. Peter and Marcellinus in Rome. The tomb is situated beneath an equites cemetery which implies a certain relation of the deceased to the social group. The excavations were conducted into areas named X80-T16 and X80-T18 of $2 \mathrm{~m} \times 1 \mathrm{~m}$ and $2.8 \mathrm{~m} \times 2.5 \mathrm{~m}$. In both cases the deceased are laid in an organized manner, next to one another or on multiple layers which can vary in thickness from $0.6 \mathrm{~m}$ (T16) to $0.8 \mathrm{~m}$ (T18). The excavation revealed nine such layers in T16 and twelve layers in T18. Those levels were created in a short period of time, comprising as much as 84 (T16) or 78 (T18) individuals. The report mentions the find of cloth fragments along with crystalized amber. The anthropological expertise has revealed that the time of death

\footnotetext{
${ }^{5}$ LITTMAN/ LITTMAN1973, 246-252.

${ }^{6}$ GILIAM 1961, 250.

${ }^{7}$ VOICULESCU1971, 89.

${ }^{8}$ VOICULESCU 1971, 92-95.

${ }^{9}$ GILIAM 1961, 228-229.

${ }^{10}$ DUNCAN-JONES 1996, 120-121.
}

was at a young adult age, with a predominance of females (72.5\%). Moreover, no trauma signs were discovered and the average height $(1.6 \mathrm{~m})$ exceeds the ancient average. These aspects, with the addition of gold fragments, suggest that the deceased had a high social status, and that they died abruptly, victims to an epidemic. The authors state that, based on the chronology of the finds, the Antonine plague is largely disqualified. Still, there is room for doubt as the possibility of a later replica of the disease, such as the one presented by Cassius Dio in 189 A.D. could be considered the culprit. ${ }^{11}$

A second mass grave which caught our interest was dug out in the archaeological investigation which took place between 2004 and 2006 in Gloucester. Unfortunately we were not able to reach the detailed publication of the site. ${ }^{12}$ Be that as it may, from the resumes gathered, we were to understand that the excavation has brought to light a mass grave with 91 individuals. Analogies with the previous example, such as the large number of victims, the chronology, the erratic burring manner, and the lack of trauma signs, have lead the scientist to consider the Antonine plague as a plausible cause for the high death-toll.

In addition, a study conducted on a number of 481 funerary stelae belonging to a typology found in the northeastern region of Lydia, which are concentrated mainly in the area of ancient Saittae reveals interesting data. ${ }^{13}$ Thus the chart attached to the study shows a significant increase of an almost double number of funerary stelae especially between 165-169 and 189-190 AD, which coincide with data written sources. ${ }^{14}$ The fact that the deceased belong to a high social class, and that raising a funeral stela is a pretty serious financial strain, ought to be considered.

\section{Dacia}

The arguments presented above come to support the theory of a wide spread epidemic throughout the Roman Empire. Unfortunately, we lack such substantial evidence in Dacia. However, we believe that there is some circumstantial evidence which when put together raises at least a discussion on this topic.

A noteworthy aspect is the transfer of Legio V Macedonia from Troesmis to Potaissa. According to available data, Legio V Macedonica is in Dacia in as soon as 168 or early 169 AD..$^{15}$ Their participation in the campaign against the Parthians is proved by inscriptions. ${ }^{16}$ This information, coupled with the epidemic break out in the same year at Aquileia and also among troops returning from war with the Parthians, can induce a similar situation. There is also an inscription that attracts attention. Raised by the centurion Vitalis C.Cassius in honor of Apollo Parthicus, the inscription was considered a shrine dedicated to the god that facilitated the victory of the Romans ${ }^{17}$. However, the Historia Augusta mentions

\footnotetext{
11 BLANCHARD/CASTEX/COQUERELLE/GIULLIANNI/RICCIARDI 2007, $989-997$.

${ }^{12}$ SIMMONDS, MARQUEZ-GRANT, LOE 2008.

${ }^{13}$ BROUX/CLARYSSE 2009, 27.

${ }^{14}$ BROUX/CLARYSSE 2009, 28.

${ }^{15}$ BĂRBULESCU 1987, 23.

${ }^{16}$ CIL III 6189 = ISCM V 159

${ }^{17}$ MACREA 1978, 98-105.
} 
that the disease started in Babylonia, when a Roman soldier accidentally destroyed a golden sarcophagus in the temple of Apollo, releasing the pestilential vapors. ${ }^{18}$ Inscriptions dedicated to Apollo meant to spare the dedicators from the epidemic exist at Hierapolis in Phrygia or at Pergamum. ${ }^{19}$

Another indicator of the situation is one of the wax-tablets from Alburnus Maior, more exactly TabCer DI. ${ }^{20}$ As it is known, the wax-tablet is actually the record of the dissolution of a funeral college. The tablet dated in AD 167 signals the dissolution of the college, citing the permanent absence of twothirds of the members who left the Alburnus. This situation resembles that of the Egyptians who leave their settlements in the same period. The tablets found in mine galleries in Alburnus were probably part of an archive that was later abandoned. The most important aspect is the fact that, the situation through which the funeral college is going before its dissolution (probably started in January when the co-magister does not return after being elected to office) is also prior to the first massive barbarian attacks which, reported after this date. Extrapolating the situation of the funeral college to all the mines in Aburnus, one can assume the abandonment of the area. An analogy might exist with some mines in the southwest of Spain. Mines undergo a deactivation between 170 and $180 \mathrm{AD}$ and notable changes also take place in the settlement and cemetery from Rio Tinto. Thus, the author names the cause of the abandonment of the mines as the decrease in the number of workers and the increase in labor costs due to the Antonine plague. The fact that this was the administrators' reaction is due to a pragmatic spirit. ${ }^{21}$

An imperial inscription from Ulpia Traiana Sarmizegetusa ${ }^{22}$ is dedicated to Marcus Aurelius (raised after the death of Lucius Verus) for saving the city from a huge danger or two great dangers. Paired with another construction votive $\operatorname{slab}^{23}$ (or rather reconstruction following its burning by foes), the event raised could be a barbaric attack during the Marcomanic wars. However, in the interpretation which highlights two great dangers, one of those could be considered the studied epidemic.

In addition, analyzing the inscriptions published in IDR (from volume II to III/5/2), and selecting those that can be classified chronologically in the period of interest for this study reveals a series of interesting data (fig. 1).

Thus, although the number of inscriptions that can be fit are deficient, one can observe a sharp and sustained decline. However, other causes that could lead to such a decrease such as the Marcomanic wars or the civil war following Commodus' death need to be considered.

\footnotetext{
${ }^{18}$ GILIAM 1961, 232.

19 JONES 2005, 297-298

${ }^{20}$ IDR I,192-198.

${ }^{21}$ SILVER 2011, 133-142.

${ }^{22}$ IDR III/2, 75

${ }^{23}$ IDR III/2, 37
}

The archaeological research at the necropolis at Apulum /"Dealul Furcilor" reveals an aspect rarely mentioned in the Roman necropolis: the presence of lime in some burial tombs. Of 21 inhumation graves, M4 (SPII), M1 (Sp I), M3 (Sp I), M6 (Sp I), M7 (Sp I), M8 (Sp I), M9 (Sp I), M10 (Sp

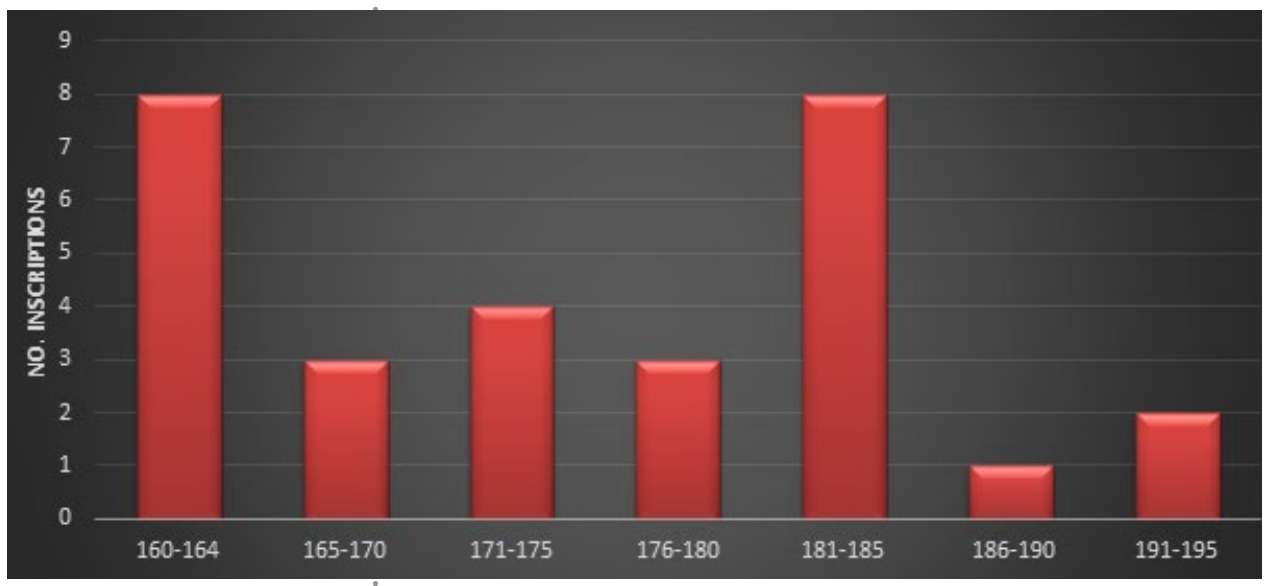

Fig. 1. Datable inscriptions in Roman Dacia

I), M17 (Sp I), M20 (Sp I) reveal the presence of lyme in the process of inhumation. Of these, only M20, M17, M9 and M1 are of adults the rest being of children or newborns. Tomb M6 is enlightening due to the fact that the lime layer kept an imprint of the body. This suggests a uniform coverage of the body, and not of the bottom of the sarcophagus. Analogies in the cemetery of Rome were presented above. Thus, although there is no form of dating (in terms of stratigraphy M17 being the oldest in a sequence of three tombs), we can assume that the use of lime in this case and the large number of infant deaths can be linked to an epidemic. The four coins discovered come from Hadrian, Antoninus Pius, Caracalla and Julia Mamaea. ${ }^{24}$

At Apulum, in the cemetery on "Dealul Podei", the archaeological investigation revealed a total of 25 tombs, 24 of them with a layer of lime on the head or upper body. 10 of these graves are of babies in the cist brick or wooden coffins. The only piece of inventory found during excavation is a coin of Julia Domna (dated between AD 196 and AD 202).

These graves, although slightly later than chronology mentioned so far (comparable to the situation in Rome in $189 \mathrm{AD}$ ) are still able to support the hypothesis of an epidemic. ${ }^{25}$

In terms of numismatic evidence (fig. 2), a sharp decrease in the amount of coins can be considered as an aspect of the economic contraction and production of currency after the outbreak of the epidemic ${ }^{26}$, but also as an effect of the Marcomanic war. ${ }^{27}$

The situation in Egypt outlined above, with the decrease in the number of taxpayers and even the decrease of the production is much better documented, especially because of

\footnotetext{
${ }^{24}$ GLIGOR/BOGDAN/MAZARE/LIPOT/BALTES 2010, 117-137.

${ }^{25}$ The epidemic has two moments of climax, in 167 A.D. and 189 A.D., but we cannot assign to it a fixed chronology. Thus, the disease may have lasted more than 189 A.D. in some areas of the Roman Empire. ${ }^{26}$ DUNCAN-JONES 1996, 132-133.

${ }^{27}$ ARDEVAN 1993, 111-113.
} 


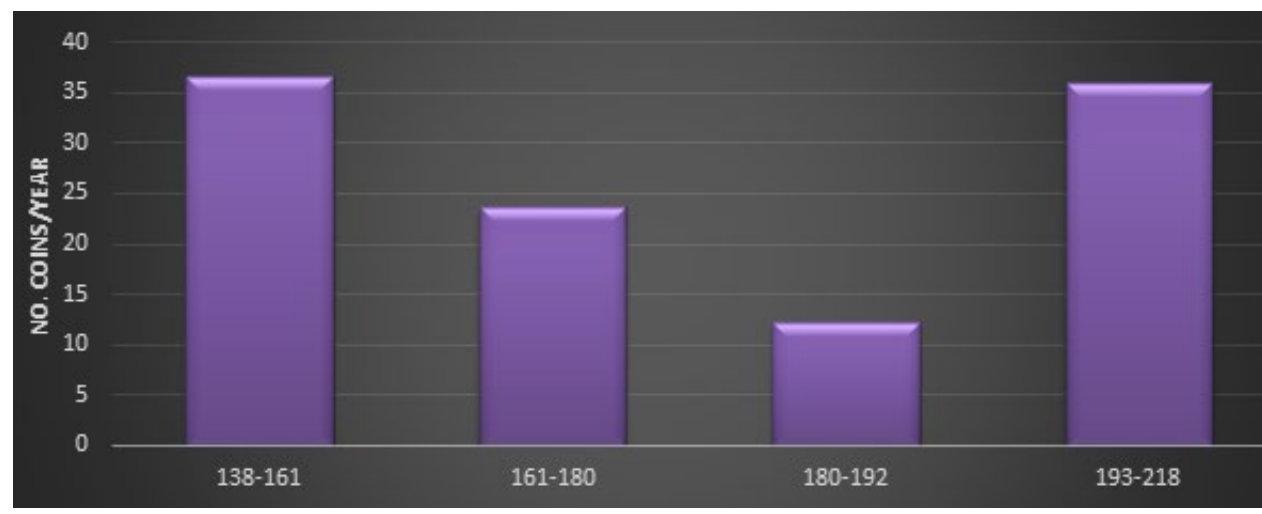

Fig. 2. Single coin finds in Roman Dacia ${ }^{28}$

papyrology sources. ${ }^{29}$ In Dacia, even if there were such documented fluctuations, the situation needs to be considered from a military point of view; troops movement related to the wars could cause disruptions in production.

\section{Moesia Inferior}

At Tomis, investigations carried out in the South-Western Roman necropolis in 1991 and the Western one in 1992, several collective tombs emerged. Archaeologists chronologically assigned them to the last quarter of the second century, which coincides with the epidemic and the replica in 189 AD. In the first campaign in 1991, amongst the graves discovered there were two collective graves named M10 and M21 with groups of six and three deceased. Both of them are niche tombs with rich inventory, the dead belonging to families whose members died simultaneously so the buried were both adults and children. ${ }^{30}$ During the second campaign, three collective burials dated to the late second century, were discovered. M37 and M44 have 3 deceased (probably parents and child), in M37 being buried in the same coffin and in M44 the adults present at $20 \mathrm{~cm}$ distance, with the baby at $15 \mathrm{~cm}$ above them. M21 is a niche tomb with two individuals (probably husband and wife). Again, grave inventory is quite rich with gold jewelry, silver and bronze, pieces of glass and pottery. ${ }^{31}$

Also, in one of the cemeteries at Tomis, the rescue excavations have brought to light a sarcophagus with an inscription from the Roman period, dated by archaeologists between the late second century and the first half of the third century, based on the funerary inventory. The interesting aspect is given by the absence of iron staples to seal the cover ark. Inside the sarcophagus two wooden coffins were found, overlapped by two sleepers. The reason for the lack of braces is that of a later introduction, above the original deceased (aged 58 according to the inscription), of a deceased teenager. Both wore robes with gold inserts at the time of burial, on the mouth of the second being seated a gold foil. ${ }^{32}$ Given the economic situation we can only assume that the members of all this died in a short time, which explains why the graves are collective, not individual.

\footnotetext{
${ }^{28}$ GĂZDAC 2008, 27.

${ }^{29}$ DUNCAN-JONES 1996, 132-133.

${ }^{30}$ BUCOVALĂ/PAȘCA 1991, 185-236.

${ }^{31}$ BUCOVALA/PASCA 1992, 241-272.

${ }^{32}$ PAPUC 1974, 307-316.
}

An impressive burial complex that was discovered in the Ostrov county in Constanta, asks a question like that of the author, on the event that brought to death five members of a fairly wealthy family, sometime in the later half of the second century. An adult male (probably pater familias), an adult woman with a child of 4-5 years, another female character approximately 20-25 years and 10-15 years adolescent are buried in this complex. The impressive aspect is given by the funerary complex fresco covering the walls with the scene of a funerary banquet that includes all members of this family. ${ }^{33}$

$$
* * *
$$

In conclusion, the present study aims to raise a question of the existence in Dacia of a disease that has affected an entire Empire. The spreading of the disease in a short time, as evidenced by written sources, epigraphic sources, archaeological excavations and its effects on the economy documented in Egypt and their correlation with some information that we have about Dacia and Moesia Inferior, are just some of the arguments that we had access to .Also, general data on the spread of such a disease may serve to observe the mechanism of an epidemic, the most relevant observation even in the study of epidemics in the third millennium. Finally, at the present state of research, the presence of the Antonine plague in these two provinces cannot be claimed with certainty. For now, we propose a review and interpretation of artifacts from the second half of the second century $\mathrm{AD}$, and we hope that conclusive results are to be expected.

\section{References}

\section{ARDEVAN 1993}

Ardevan, R., Circulatia monetară în assezarea romană de la Gherla (jud. Cluj), EphemNap 3, 111-122

BĂRBULESCU 1987

Bărbulescu, M. Din istoria militară a Daciei romane. Legiunea V Macedonica și castrul de la Potaissa (Cluj-Napoca: Dacia)

BLANCHARD/CASTEX/COQUERELLE/GIULIANI 2007

Blanchard, P./ Castex, D./ Coquerelle, M./ Giullianni, R./ Ricciardi, M., A mass grave from the catacombs of Saint Peter and Marcellinus in Rome, second-third century AD, Antiquity 81, 989-998

\section{BROUX/CLARYSSE 2009}

Broux,Y./ Clarysse, W., Two Greek funerary stelae from Lydia and the Antonine Plague, Tyche 24, 27-33

BUCOVALÄ/PAȘCA 1991

Bucovală, M./ Pașca, C., Descoperiri recente în necropola romană de sud-vest a Tomisului, Pontica 24, 185-236

BUCOVALĂ/PAȘCA 1992

Bucovală, M./ Pașca, C., Cercetări în necropola romană de vest a Tomisului, Pontica 25, 241-272

${ }^{33}$ CHERA-MĂRGINEANU 1978, 137-141. 


\section{CHERA-MĂRGINEANU 1978}

Chera-Mărgineanu, C., Un mormânt de epocă romană descoperit pe raza comunei Ostrov, Pontica 11, 137-141

CREVIER 1814

Crevier, J.B.L, History of the Roman Emperors from Augustus to Constantine (London: Longman)

DUNCAN-JONES 1996

Duncan-Jones R.P., The impact of the Antonine plague, JRA 9, 108-136

GĂZDAC 2008

Găzdac, C., Aspects of coin circulation in Roman Dacia. In Bursche, A./ Ciołek, R./ Wolters, R. (eds.), Roman coins outside the Empire: ways and phases, contexts and functions. Proceedings of the ESF/SCH Exploratory Workshop, Radziwill Palace, Nieborow (Poland), 3-6 September 2005 (Wtteren: Moneta), 269-294

GILIAM 1961

Giliam, J.F., The plague under Marcus Aurelius, AJPh 82/3, 225-251

GLIGOR/BOGDAN/MAZARE/LIPOT/BALTEȘ 2010

Gligor, M./ Bogdan, D./ Mazare, P./ Lipot, Ș./ Balteș, G., Morminte romane din necropola de pe Dealul Furcilor de la Apulum, Terra Sebus 2, 117-139
JONES 2005

Jones, C.P. Archaeological Reports and Notes: Ten Dedication "To the gods and goddesses" and the Antonine Plague, JRA 18, 293-305

LITTMAN/LITTMAN 1973

Littman, R.J./ Littman M.L. Galen and the Antonine plague, AJPh 94/3, 243-255

MACREA 1978

Macrea, M., Apollo Parthicus. In Bărbulescu (ed.), De la Burebista la Dacia postromană: repere pentru o permanență istorică (Cluj-Napoca: Dacia), 98-105

PAPUC 1974

Papuc, G., Un sarcofag de epocă romană din Tomis, Pontica 7, 307-316

SILVER 2011

Silver, M., Antonine plague and the deactivation of spanish mines, Arctos 45, 133-142

SIMMONDS/MARQUEZ-GRANT/LOE 2008

Simmonds, A./ Marquez-Grant, N./ Loe, L., Life and death in a Roman city (Oxford: Oxford Archaeology)

VOICULESCU 1971

Voiculescu, M., Boli infecțioase (București: Medicală) 